\title{
The role of Brand Salience and Trust in deepening Perception to an Intention: An Empirical study on a Social Media Platform
}

\begin{abstract}
Imran Munawar Qureshi ${ }^{1}$, Hafiz Ghufran Ali Khan'², Abdul Zahid Khan ${ }^{3}$
${ }^{1}$ Assistant Professor, Faculty of Management Sciences, International Islamic University, Islamabad ${ }^{2}$ Assistant Professor, Faculty of Management Sciences, International Islamic University, Islamabad ${ }^{3}$ Assistant Professor, Faculty of Management Sciences, International Islamic University, Islamabad

\section{A B S T R A C T}

This paper aims to consider the effects of trust and brand salience between perception-Intention relationships. For this purpose, an internet survey was conducted and analyzed through SEM. The results indicate that in the presence of developed consumer perception, trust and brand salience do not show any significant effect on Intention to transact. However, independently brand salience and trust have significant relationships with the Intention to transact. There is no significant mediating effect of brand salience or trust in deepening consumer perception to the level of 'Intention to transact'. This study recommends determining the key variables that affect the deepening of consumer perception. From a practical point of view, this study suggests that firms using social media platforms should concentrate more on creating a good perception about their products and brands. A perceptual position properly created and managed has a very good chance of converting into an Intention to perform a transaction. This study provides valuable insight into social media users' behavior regarding their Intention building through the use of social networking sites. Furthermore, this study extends the deepening of consumer perception to the level of 'Intention to transact' by examining the mediating role of trust and brand salience.
\end{abstract}

Keywords: Social Networking Sites, Consumer Perception, Brand Salience, Trust, Intention to Transact, Online Environment, Online Shopping

\section{INTRODUCTION}

The virtual world formed through Social Networking Sites (SNS) on the internet, accessible through wired, wireless and telecom networks, is the new frontier for marketing. This virtual world is activated through the pervasiveness of new media. In a phenomenological sense, the new media is composed of mobile networks and the internet. Each platform provides some general and unique potential by offering 
interactional usefulness with customers. At first, the platforms were particular media like email, which was specific to the internet and an SMS specific to a telecom network. Now the emergence of new media and consequently, platforms are also getting meshed by increasing complexity. Currently, sending an SMS through a website and doing a video chat through social media sites is rapidly multiplying the options of interactivity. These new technologies have significantly changed our lives (Lowe, Dwivedi \& d'Alessandro, 2019).

A recent example is the use of Virtual Try-on Technology for increasing the purchase intention of garments available online, studied by Zhang, Wang, Cao, \& Wang (2019). Furthermore, new technologies have given rise to the sharing economy which has made platforms supersede as the preeminent institutions in society (Sudarajan, 2019). The majority of researchers in this area concerning end-user/consumer behavior towards new media has been conducted from the perspective of Information Systems and ECommerce. There are few studies on the impact of telecommunication networks and its platforms specially SMS and MMS. Some literature is available presenting new media as a tool for marketing. Literature suggests that the effects of E-Marketing stimuli on consumer behavior is a scantly explored area that is increasingly gaining the attention of researchers. Few studies have attempted to explore different aspects of consumer behavior in terms of their response to websites. The most sought after area is the development of trust in new media and new media carrier platforms.

Social media is a platform, that is perpetuated through internet or mobile telecommunication networks media. Social media has a lot of potential, as it provides a very engaging experience to users. Its phenomenal growth in terms of number of users, as well as its pervasive availability as a basic feature in most current and upcoming telecommunication devices, has made it the new frontier for marketing. There are many challenges faced by marketers in navigating through new media. First of all the lack of physical interactivity cancels out all the non-verbal cues that are essential in perception formation. The second issue is the viral nature of the SNS media platform, which makes it difficult to manage the marketing effort. This study is an effort to understand the basic dynamics of consumer perception. The researchers posit that trust and brand salience 
have a critical role in deepening consumer perception to the level of Intention or Intention to perform a transaction in a social media platform provided environment. Recent studies have concentrated more towards the antecedents and outcomes of the customer's experience in the online shopping environments, a study by Bilgihan, Kandampull and Zhang (2016) attempts an effort towards creating a unified model for online shopping environments. A study by Grewal and Stephen (2019) suggests that people have a higher intention towards purchase if they find that a review posted online was done through a mobile device. Another major research direction is looking at the effectiveness of the institutional effectiveness of the E-Commerce mechanism with respect to the institution and its technologies. An interesting study by Fang, Qureshi, Sun, McCole, Ramsey and Lim (2014) on the issue of perceived effectiveness of E-Commerce Institutional mechanisms in generating behavioral outcomes like trust, online repurchase intention and satisfaction, is a clear indicator of this research direction. There is still quite a lot of scope for work in uncovering the actual perceptual and behavioral mechanisms in online environments.

Following are the research objectives of this study:

- To study the deepening of perception, to the level of Intention, in a social media environment.

- To explore the role of brand salience in graduating consumer perception to the level of 'Intention to transact' in a social media environment.

- To explore the role of trust in graduating consumer perception to the level of 'Intention to transact' in a social media environment.

\section{LITERATURE REVIEW}

\subsection{Trust}

Trust as a concept is something that encompasses the whole human sociological condition. Its application in some areas is more pronounced like in matters of public affairs as in some places more subtle but equally important in one to one relations like that of a husband and wife. In marketing, the term Trust is a willingness to rely on an exchange partner at whom one has confidence (Moorman et. al, 1993). Many Sociologists distinguish between trust in any societal structure or arrangement and face to face trust (Barber, 1983; Giddens, 1990; Good, 1988). Although in economic terms Trust 
is thought of as the fluid that maintains an economic structure which is epitomized by money or currency that circulates in an economic structure. However, trust in such abstract systems is devoid of an emotional element (Dasgupta, 1988; Good, 1988).

Trust in an online environment, particularly for a website, is constituted by perceived honesty, benevolence and competence. As there is no physical interaction between the transacting entities (Flavian \& Guinaliu, 2006), therefore, all the elements of non-verbal communication and feel elements are taken out of the purchasing experience. Another crucial aspect is the financial aspect of the transaction. In a normal transaction, the financial element has minimal risk as the exchange takes place on-site. In an ecommerce setting the financial element is protracted and the risk of a fraud remains for a longer time.

Similarly the physical exchange of goods is also a delayed experience that gives rise to uncertainty and mistrust (Flavian \& Guinaliu, 2006). It is then accurate to state that internet transactions have a high element of risk. Consequentially it is much harder to develop Trust in an eCommerce setting as compared to traditional channels (Bitting and Ghorbani, 2004).

As posited by McKnight and Chervany (2002) there are three types of trust based on the entities involved in a transactional setting. The first type is the 'disposition to trust, which is specific to the truster. This concept comes from psychology and economics and is defined in simple terms as trust in general others. This carries a sense of reinforcement after every situation encountered by the truster. In an e-commerce environment, this concept is considered to have an initial impact on people who start to use the Internet as a medium of transaction. Applying this concept to E-Marketing there would be certain modifications to the concept. First of all the nature of the construct is different. In EMarketing, each electronic message will reinforce the disposition to trust positively or negatively. The second type of trust defined by McKnight and Chervany (2002) is 'institutional trust'. This construct emanates from the realm of Sociology and is thought of as trust in the situation and structures. In the context of the Internet, "favorable conditions" are referred to as the legal, business, technical and regulatory aspects of the overall environment perceived to support success. Sociology is the origin of this 
construct positing that people can rely on others that things will go well because of structures, situations, or roles that provide assurances (Baier, 1986). For this study, this concept includes the above-mentioned ideas, regarding the Internet as the framework providing along with other E-Marketing mediums like mobile phone communication and the company sending the marketing stimuli is considered to be the 'institution' in question. The third type of trust defined by McKnight and Chervany (2002) is 'interpersonal trust'. This concept is common in the areas of Sociology, Psychology and Economics. This type addresses specific individuals/institutions that form the trustee in a transaction. In the context of E-Marketing, this would mean the individual customer or company to whom the E-Marketing stimulus is targeted towards. What this research target is the impact of these types of trust on consumer perception emanating from an EMarketing effort.

Trust is a complex concept which has many dimensions to it. Essentially trust is taken more of as a transactional entity in most of the E-commerce literature as compared to other disciplines that view trust more as a sociological construct. Although there are dispositional elements to trust as well, as a study by Herrando, Jimenez-Martinez, \& Martin-De Hoyos (2019) suggests that different age cohorts form trust differently in an online context. Trust in this study is taken as a transactional construct that is formulated as a systemic effect of the impact of a stimulus. Results of research by Ardyanto (2015) show a significant influence of trust on online purchasing decisions, trust in e-commerce and ease have a simultaneously significant effect on online purchasing decisions. The study provides empirical evidence that there is a significant and positive effect cast on the intention to buy from a website by trusting beliefs (Stewart, 2003). According to Das and Teng (2004), Trust is the mirror image of risk. In the context of online reviews, images help in improving trust in review and purchase intention (Zinko, Stolk, Furner, \& Almond, 2019)

\subsection{Intention to Transact}

The relationship between Intentions carries a major assumption that human beings depend on available information to make rational decisions. Thus, a person's actual behavior is a direct consequence of the Intention to perform (or not to perform) a 
behavior (Ajzen and Fishbein, 1980). On the foundations of the Technology Acceptance Model (Davis, 1989), Theory of Reasoned Action (TRA) (Fishbein and Ajzen, 1975), and Theory of Planned Behavior (Arzen, 1991), a healthy number of e-commerce studies show consumer intentions to engage in online transactions to be a significant predictor of consumers' actual participation in performing E-Commerce transactions (Pavlou and

Fygenson, 2006). According to Zwass (1998), intention to transact is defined as the "consumer's Intention to engage in an on-line exchange relationship with a Web retailer, such as sharing business information, maintaining business relationships, and conducting business transactions". The main antecedents for determining consumer acceptance of e-commerce are Intention to transact and on-line transaction behavior (Pavlou, 2003). A study by Nysveen et. al, (2005) shows significant evidence for the effects of perceived control, normative pressure, attitudinal influences and motivational influences on consumers 'intentions to use mobile services. From a marketing point of view, in this study 'Intention to transact' is taken as the intention to perform an actual business transaction, this is akin to purchase intention. In a study by McClure \& Seock (2019) it is found that social media page content creates a positive attitude towards a brand improving future purchase intention. Furthermore, involvement with brand increases but it may not increase future purchase intention. Chakraborty (2019) suggests that purchase intention is enhanced by the effect of perceived value and brand awareness. For purchasing intention of new products, campaign characteristics affect consumer attitude which leads to higher purchase intention (Baum, Spann, Füller \& Thürridl, 2019). From the perspective of online reviews, a study by Thomas, Wirtz \& Weyerer (2019) suggests that review credibility determined through argument quality and peripheral cues has a positive effect on purchase intention.

\subsection{Consumer Perception}

The I-P-R model which comes under the umbrella of S-O-R paradigm, along TRA gives a strong direction that a stimulus interacting with an organism induces certain processes culminating in a reaction. Using the same concept, marketing stimuli initiate processes in the mind of the consumer that culminate in a buying decision and eventually a purchase. The first stage in the processes is the formation of a perception which then 
deepens to form an Intention. TAM is considered as a special case of TRA (Pavlou, 2003). The basic premise of TRA is that individuals are rational in terms of information processing and they use available information in a systematic manner (Belleau et. Al, 2007). The information processing at first creates a perception that converts into a purchase Intention on reinforcement. Consumer perception in itself is a vast area that has many angles from which it has been investigated. To study the effects of new media in marketing terms in this study, the technology angle of perception is used as presented by TAM. User behavior can very succinctly be explained by TAM (Davis et. al, 1989; Klopping and McKinney, 2004). Core determinants of user behavior deliberated on by Davis (1989) are 'Perceived Ease of Use' and 'Perceived Usefulness'. Considering the phenomenon of online shopping, three types of risks exist. Foremost is 'financial risk', secondly 'product risk', and thirdly 'information risk' (security and privacy) (Bhatnagar et. $\mathrm{Al}, 2000)$. Product risk is associated with the product itself; like the product may turn out to be defective. Moreover, there is transportation risk as well as taking possession of the product. In the case of online purchasing financial risk, including opportunity cost and time, is related not to the product but to the marketing channel (the Internet). Information risk associates with privacy and transaction security; for instance, the requirement that a consumer may have to submit credit card information through the Internet may evoke the possibility of credit card fraud (Fram et. al, 1997).

The concept of 'value' is one of the core concepts in marketing detailing the overall physical, psychological and societal benefits of any product or service. Zeithaml (1988) defines value as "the consumer's overall assessment of the utility of a product based on perceptions of what is received and what is given." Holbrook (1999) defines consumer value as "an interactive relativistic preference experience" (p. 5), with perceived value encompassing all of the hedonistic, affective and subjective hedonistic dimensions of the consumer experience. As Parasuraman and Grewal (2000) posit, perceived value is a function of "a 'get' component-i.e., the benefits a buyer derives from a seller's offering — and a 'give' component-i.e., the buyer's monetary and nonmonetary costs in acquiring the offering." Perceived value is considered as a crucial antecedent of loyalty (Harris and Goode, 2004). The perceived value consists of 
components like the image of the product performance in the customer's cognition, channel deliverables, quality of warranty offered, customer support, and some softer attributes including supplier's reputation, trustworthiness, and esteem (Kotler and Keller, 2006). The perceived value increases the intention to purchase as well as loyalty by reducing consumers' motivation to seek information on alternatives. When customers are satisfied, they may perceive that they are receiving "best value" consequently losing the motivation to pursue gathering information on alternatives (Anderson and Srinivasan, 2003).

\subsection{Brand Salience}

Keller (1993) outlined the concept of Brand Salience in the "Customer-Based Brand Equity Model" (CBBE). It is a milestone in conceptualizing the path for companies in their journey towards building strong brands. The CBBE model gives a path to organizations in managing brand equity by recognizing the importance of customers. Alba and Chattopadhyay (1986) define brand salience as "propensity of brands, to be thought of by buyers or level of activation of a brand, in memory at the point of purchase." According to Remaud and Lockshin (2009) Brand Salience refers to the "reflex in which a particular brand comes to mind when talking about products related to the brand's products". This definition of brand salience considers the subconscious level and focuses on the recentness of the brand at that level. A top-of-mind recall is also a phenomenon explaining the same concept. A message communicated through EMarketing will influence the cognitive domain of the recipient and create a perception. A perception formed will differ if the brand name is known as compared to if the brand name is not known. Enhance consumer engagement by brands in-terms of online microblogging has a positive effect on brand salience (Zhao, Cheng, Wang \& Qin, 2019).

The study by Pavlou (2003) suggests that in the presence of information technology, TAM is a useful model in explaining purchase intentions. In this study, considering an e-commerce environment, perceived usefulness is found to be a strong predictor of intentions to transact. Findings suggest that consumers view the transaction process in its entirety both as an intention to transact (product purchase) and intention to use (information exchange), even if the process spans a bunch of activities. Future 
research direction mentioned in Pavlou's study is to further examine the complex interrelationship among trust, perceived risk, and behavioral intention to develop some empirical conclusions.

Kim et al. (2008) suggest in their recommendations for future research that trust should be positioned as a moderator of the relationship between perceived risk and purchase intention. They further suggest to consider alternative models explaining relationships among trust, risk, purchase intentions and decisions, and their antecedents, the various conditions under which the models may or may not hold, and ways in which the models might potentially be integrated. Koufaris and Hampton-Sosa (2004) established the relationship between different constructs of perception including initial trust in an online company, perceived ease of use, perceived usefulness and perceived security control.

To put the whole argument into perspective, as established through the S-O-R paradigm and I-P-R model, thoroughly studied as the perception formation process, marketing stimuli initialize the consumer process. This perception is thought of as a twostage process. At first, there is an initial perception formed which then further deepens and converts into an intention to transact. The first step then is to determine the impact of marketing stimuli reaching the customers through new media. In the deepening of consumer perception to the level of intention to transact, trust and brand salience are determined to play a decisive role. This is consistent with the integrative model of consumer behavior presented by Taylor and Strutton (2010).

Conceptual Model:

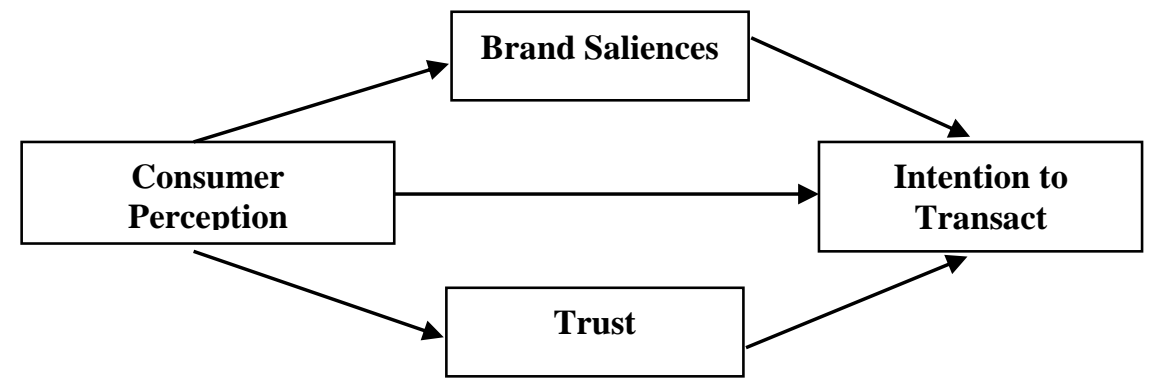

Figure 1: Proposed mediating role of Brand Salience and Trust 


\subsection{Consumer Perception and Intention to transact}

The S-O-R paradigm portrayed by Houston and Rothschild (1977), along with TRA gives a direction that the formation of 'perception' induced by a marketing stimulus culminates in a buying decision (Qureshi et al., 2011). Perception is a subjective term and it is a process of selecting, organizing and interpreting information to form a purposeful picture of the world. Consumer perception can be determined by past experiences, perceived usefulness, perceived ease of use and risk of Internet security (Wiesberg et al., 2011). Due to temporal distances, online experiences are different than the brick and mortar mode. It has been noted that consumers have several concerns on the web-based information and transactions (Constantinides, 2004). These concerns either create or impede the consumer perception's to transact or not to transact by the social networking sites. Normally, consumers' perceptions based on good past experiences, and feeling no risk factor through the use of social media environment have better intention to transact. In the context of gaming, consumer perception of CSR activities by a gaming company activates self-esteem and compassion, which improves the intention to purchase (Bae, Park \& Koo, 2019). Accordingly, it is expected that consumer perception has a significant influence on the Intention to transact. H1 is proposed as follows:-

$\boldsymbol{H}_{1}$ : Consumer perception has a significant effect on Intention to transact in a social media environment.

\subsection{Trust and consumer perception}

The S-O-R paradigm portrayed by Houston and Rothschild (1977), along with TRA gives a direction that the formation of 'perception' induced by a marketing stimulus culminates in a buying decision (Qureshi et al., 2011). Perception is a subjective term and it is a process of selecting, organizing and interpreting information to form a purposeful picture of the world. Consumer perception can be determined by past experiences, perceived usefulness, perceived ease of use and risk of Internet security (Wiesberg et al., 2011). Due to temporal distances, online experiences are different than the brick and mortar mode. It has been noted that consumers have several concerns on the web-based information and transactions (Constantinides, 2004). These concerns either create or impede the consumer perception's to transact or not to transact by the social networking 
sites. Normally, consumers' perceptions based on good past experiences, and feeling no risk factor through the use of social media environment have better intention to transact. In the context of gaming, consumer perception of CSR activities by a gaming company activates self-esteem and compassion, which improves the intention to purchase (Bae, Park \& Koo, 2019). Accordingly, it is expected that consumer perception has a significant influence on the Intention to transact. H1 is proposed as follows:-

$\boldsymbol{H}_{2}$ : Trust has a significant mediating effect between Consumer Perception and Intention to transact.

\subsection{Brand Salience and Consumer Perception}

The concept "Salience" is most commonly linked with "the ability of an item to 'stand out' from its environment or background" (Guido, 1998). Brand Salience as proposed by Keller (1993) in the CBBE Model is defined as "propensity of brands, to be thought of by buyers as level of activation of a brand, in memory at the point of purchase" (Alba \& Chattopadhyay, 1986). This in fact reflects the quality (how fresh and relevant) and quantity (how many) of network of information about the brands. Little information exists about the product effect on brand salience at the point of purchase (Bannerjee, and Yadav. 2012). If salient information is recalled earlier, the consumer may make earlier decisions that show consumer's intention to transact with the e-vendor (Ambler et al., 2004). In prior research, brand salience has been linked positively with behavior (Ambler, 2003; Vieceli \& N. Shaw, 2010). A highly salient brand engenders more favorable brand attitudes than a less salient brand (Stokburger-Sauer, Ratneshwar, \& Sen, 2012). Accordingly, it is expected that brand salience will mediate the relationship of consumer perception and Intention to transact. Hypothesis (H3) sheds light on the mediating relationship between consumer perception and intention to transact in a social media environment as under:-

$\boldsymbol{H}_{3}$ : Brand Salience has a significant mediating effect on the relationship between Consumer Perception and Intention to transact.

According to a study on advergaming by Choi (2019), coongruence of characters with the consumers leads to higher brand trust which in-turn increases purchase intention. 


\section{RESEARCH METHODOLOGY}

The population under study cannot be fixed to a specific area as SNS is a virtual platform with global reach. In this regard, the population then becomes all the users of SNS. Although this seems a continent sweeping statement, in reality, many issues need consideration in conducting studies on SNS. Any ad endorsed by a user will become available to their friends and contacts. For friends who are inactive communication, the endorsement will create a strong impact. For dormant or occasional contacts, the impact is either weak or delayed. Another issue that needs consideration is, the identification of target segments, as well as selecting the right forums and groups on SNSs where higher concentrations of the concerned target markets are available. It's just like identifying the right coral clusters for finding the right type of fish. The sample of the study was more focused in a university setting. This study used Facebook as the main SNS to conduct a survey. Some leads were also generated through Google+ and Linked-in. The researcher selected an ad campaign of a wireless internet service provider.

The ad was placed on the 'wall' of the researcher's Facebook account. An internet survey was created on an online website and the link of the site was placed along with the ad on the wall. A scale developed by McKnight and Chervany (2002) based on the definitions of institutional trust, a disposition to trust is used. Some items for each type of trust are also adapted from the instruments used by Kim et al. (2008), Walczuch and Lundgren (2004), Koufaris and Hampton-Sosa (2004) and Jarvenpaa et al. (2000). The construct of intention to transact is from the study of Kim et al. (2008). For brand salience, the scale was adapted from the scales used by Alba and Chatthopadhyay (1986) and Romaniuk and Sharp (2004). The construct of Consumer perception is adapted from the scales used Wang and Head (2007) and Kim et al. (2008). The same questions were used in the E-Marketing stimuli study by Qureshi, Khan and Ahmad (2011). The ad was shared and re-shared for a period of two weeks. In this time frame about 140 responses were solicited. For analysis, SEM is carried out using AMOS.

\subsection{ANALYSIS}

The campaign ad was placed on the facebook 'wall' of the researcher; the 
responses were obtained in-vivo without any controlled settings.

\begin{tabular}{|c|c|c|c|}
\hline Factor (s) & Items & Estimate & Cronbach Alpha \\
\hline \multirow[t]{4}{*}{ Intention to Transact } & ITT1 & 0.85 & \multirow{4}{*}{0.902} \\
\hline & ITT2 & 0.85 & \\
\hline & ITT3 & 0.86 & \\
\hline & ITT4 & 0.87 & \\
\hline \multirow[t]{6}{*}{ Brand Salience } & BS1 & 0.43 & \multirow{6}{*}{0.838} \\
\hline & $\mathrm{BS} 2$ & 0.75 & \\
\hline & BS3 & 0.82 & \\
\hline & BS4 & 0.78 & \\
\hline & BS5 & 0.74 & \\
\hline & BS6 & 0.56 & \\
\hline \multirow{6}{*}{ Perceived Usefulness } & PU1 & 0.72 & \multirow{6}{*}{0.867} \\
\hline & PU2 & 0.56 & \\
\hline & $\begin{array}{l}\text { PU3 } \\
\end{array}$ & 0.71 & \\
\hline & PU4 & 0.84 & \\
\hline & PU5 & 0.71 & \\
\hline & PU6 & 0.72 & \\
\hline \multirow{4}{*}{ Perceived ease of use } & PEU1 & 0.66 & \multirow{4}{*}{0.777} \\
\hline & PEU2 & 0.69 & \\
\hline & PEU3 & 0.81 & \\
\hline & PEU4 & 0.59 & \\
\hline \multirow[t]{4}{*}{ Perceived Value } & PV1 & 0.79 & \multirow{4}{*}{0.9} \\
\hline & PV2 & 0.78 & \\
\hline & PV3 & 0.86 & \\
\hline & PV4 & 0.91 & \\
\hline \multirow[t]{4}{*}{ Perceived Risk } & PR1 & 0.29 & \multirow{4}{*}{0.678} \\
\hline & PR2 & 0.76 & \\
\hline & PR3 & 0.74 & \\
\hline & PR4 & 0.63 & \\
\hline \multirow[t]{6}{*}{ Institutional Trust } & IT1 & 0.71 & \multirow{6}{*}{0.849} \\
\hline & IT2 & 0.69 & \\
\hline & IT3 & 0.73 & \\
\hline & IT4 & 0.68 & \\
\hline & IT5 & 0.64 & \\
\hline & IT6 & 0.56 & \\
\hline \multirow[t]{4}{*}{ Interpersonal Trust } & IPT2 & 0.71 & \multirow{4}{*}{0.775} \\
\hline & IPT3 & 0.59 & \\
\hline & IPT4 & 0.68 & \\
\hline & IPT5 & 0.66 & \\
\hline \multirow[t]{6}{*}{ Dispositional Trust } & DT1 & 0.71 & \multirow{6}{*}{0.677} \\
\hline & DT2 & 0.74 & \\
\hline & DT3 & 0.69 & \\
\hline & DT4 & 0.63 & \\
\hline & DT5 & 0.61 & \\
\hline & DT6 & 0.51 & \\
\hline
\end{tabular}


Cronbach's Alpha values given in column 4 of table 1 show construct reliability. Most of the values are above or very close to the acceptable value of 0.7. So, all the constructs are carried forward for further analysis. Construct validity is judged through CFA. All items showed significant factor loading. The values in table 1 indicate the loadings of items used to determine Consumer Perception, Trust, Brand Salience and Intention to transact. Consumer perception measures on four dimensions, namely perceived usefulness, perceived ease of use, perceived value and perceived risk. Trust measures three dimensions namely institutional trust, interpersonal trust and dispositional trust. Most of the items have beta values near 0.5, except PR1, which shows a loading value of 0.29 .

The Structural Equation Modeling (SEM) is applied to see the interactional effects of the variables and to check the hypothesis. In the first iteration, perceived risk indicates a negative correlation with the factor of consumer perception so it was eliminated from the model (depicted in Figure 3).

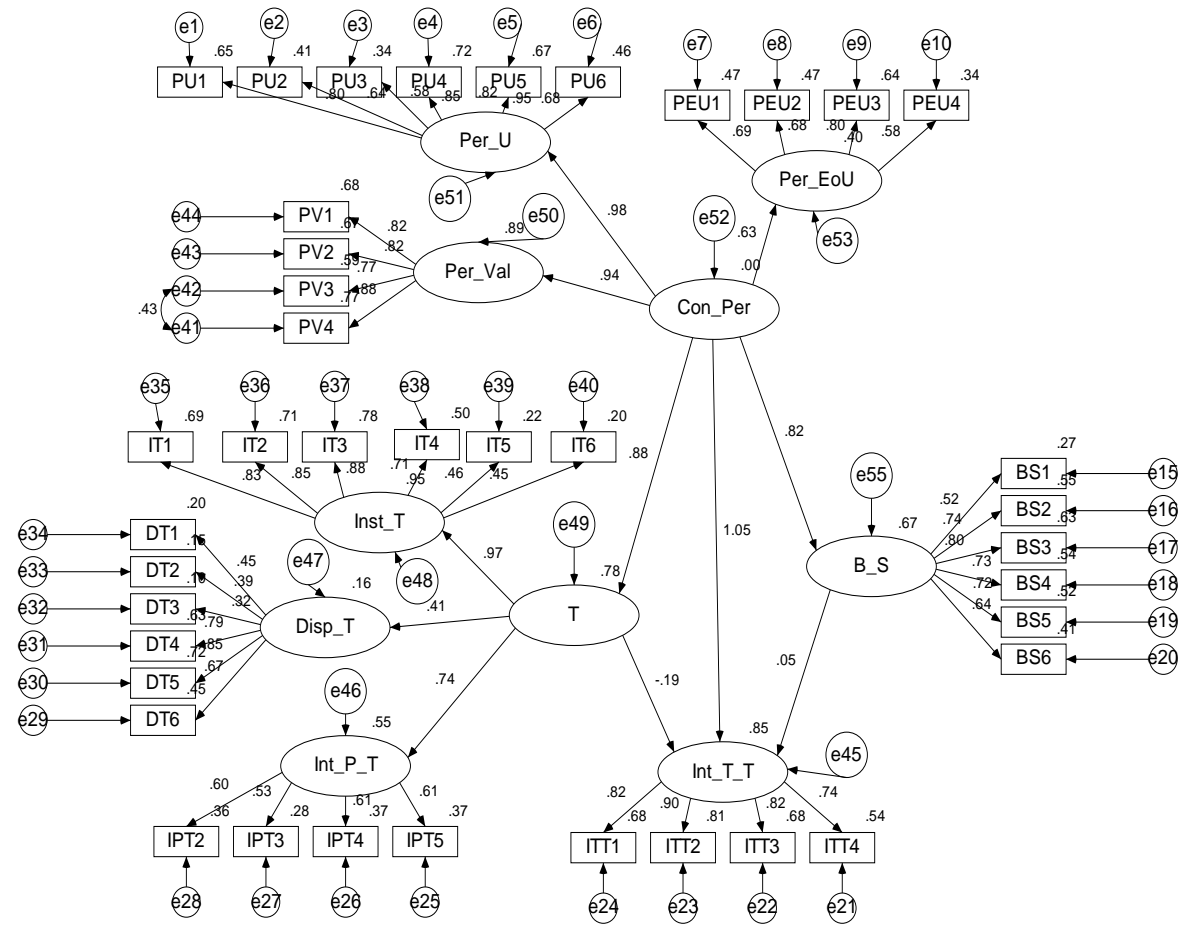

Figure 2: SEM to test the mediating effect of brand salience and trust - Initial model 
The next step shows that the specified model explains $85 \%$ of the variation in intention to transact. Consumer perception's direct effect shows a beta value of 1.05 on an intention to transact. It also has a strong effect separately on brand salience (beta value -0.82 ) and trust (beta value -0.88 ). Trust and brand salience shows insignificant beta values with intention to transact in the presence of consumer perception. Although the results are interesting but model fit is not achieved.

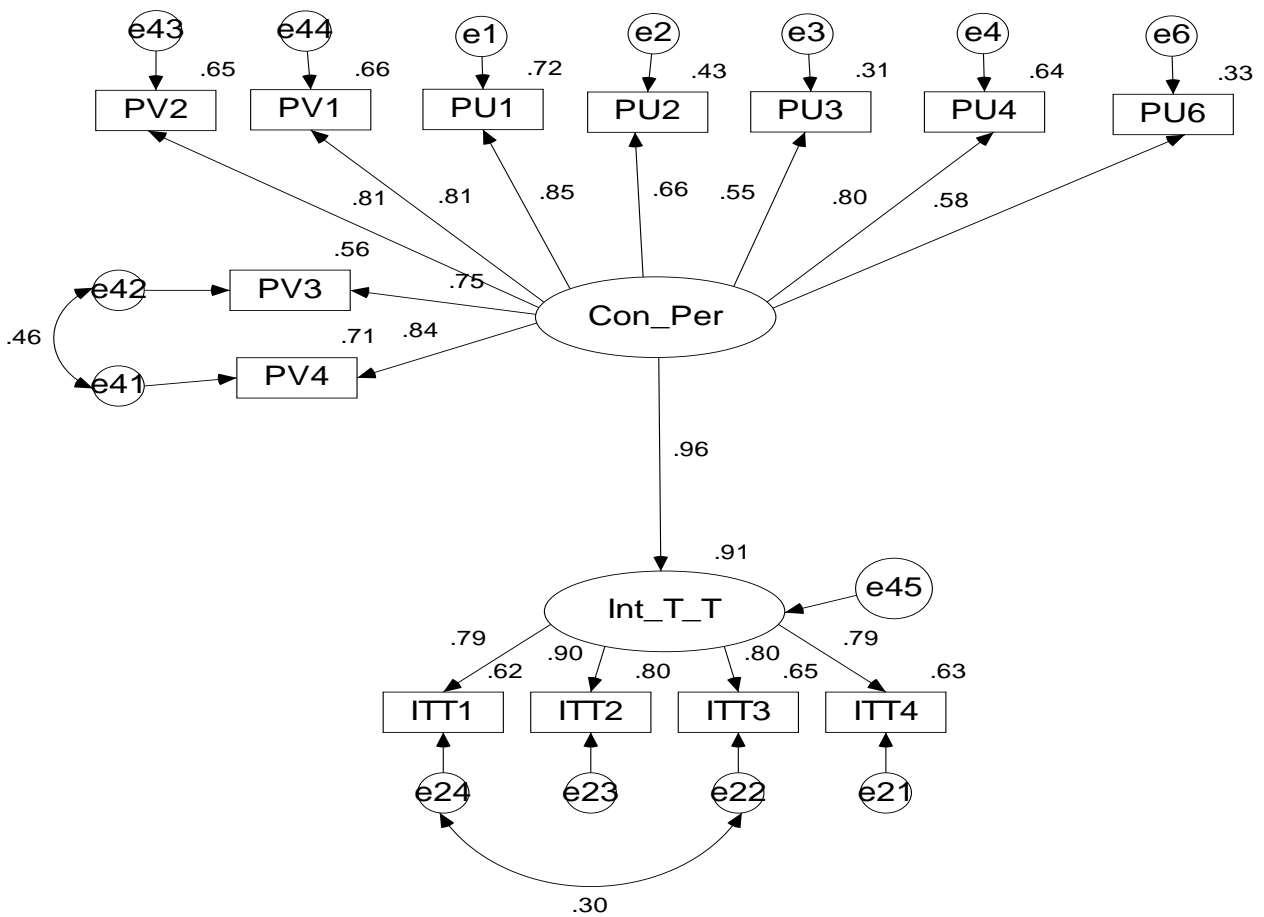

Figure 3: SEM to test the mediating effect of brand salience and trust - Fitted model

The figure above (figure 4) shows a fitted model. Model fit indices values are as follows.

\begin{tabular}{|c|c|l|}
\hline Table 2: Model Fit Values and Suggested Guidelines \\
\hline Model Fit Indices & Values & Suggested guidelines \\
\hline $\mathrm{x}^{2} / \mathrm{df}$ & 1.87 & Less than 3 \\
\hline CFI & 0.96 & Equals to or greater than 0.9 \\
\hline TFI, IFI & 0.96 & Equals to or greater than 0.9 \\
\hline TLI or NNFI & 0.95 & Equals to or greater than 0.9 \\
\hline RMSEA & 0.08 & Fair fit at and below 0.8 \\
\hline LO 90 \& HI 90 for RMSEA & 0.06 and 0.10 & $90 \%$ confidence interval \\
\hline Source: Arbuckle (2006), McDonald \& Ho (2002) \\
\hline
\end{tabular}


The dimension of ease of use of consumer perception is not present in the fitted model. All the other dimensions, though maintain their representation in defining consumer perception. Consumer perception shows a very strong effect on the intention to transact as the beta value of 0.96 indicates. About $91 \%$ of the variation in intention to transact is, explained by consumer perception. This is much better than the unfitted model, which has the interactive effects of trust and brand salience as well. In the light of this analysis we would accept hypothesis 1 and fail to accept hypothesis 2 and 3 .

\section{DISCUSSION AND CONCLUSION}

This paper studies the deepening of perception to the cognitive level of intention to transact in a perceptual thought process instigated by stimuli received by a consumer on a social media platform. Results indicate that although independently brand salience and trust have significant relationships with the intention to transact, in the presence of developed consumer perception, trust and brand salience do not show any significant effect on the intention to transact. There is no significant mediating effect of trust or brand salience in the deepening of consumer perception to the level of 'Intention to transact'. The fitted model shows that perception that is formed can easily become intention to transact, as indicated by the strong impact and variance statistics. From a practical point of view, this study suggests that firms using social media should work hard on creating a good perception about their products and brands through SNS. A perceptual position properly created and managed has a very good chance of converting into an intention to perform a transaction.

Furthermore, as this is a cognitive process, there are no physical clues available. More research is required to determine the key variables that affect this deepening of perception. There is a good direction given in a study by Hollebeek \& Mackay (2019), which suggests that digital content marketing helps in generating perception which leads to trust at different levels. Further studies can look at exploring a moderating role for trust and brand salience in deepening perception of the level of intention. Another angle for further research is the movement from cognitive to affective level. Perception is part of cognition but 'Intention to transact' in itself is an affective process. Exploration of factors 
that facilitate this movement in new media platforms in general and social media platforms, in particular, is an interesting area of future research.

\section{REFERENCES}

Ajzen I. M. \& Fishbein M. (1980). Understanding Attitude and Predicting Social Behavior, Prentice-Hall, Inc., Englewood Cliffs, NJ, 1980

Alba, J.W. \& Chattopadhyay, A. (1986). Salience Effects in Brand Recall. Journal of Marketing Research. 23(4), 363-369.

Ambler, T. (2003). Marketing and the bottom line: The marketing metrics to pump up cash flow. London: Pearson Education.

Ambler, T., Braeutigam, S., Stins, J., Rose, S., \& Swithenby, S. (2004). Salience and choice: Neural correlates of shopping decisions. Psychology and Marketing, 21, 247-261.

Arzen, I., (1991). The theory of planned behavior. Organizational Behavior and Human Decision Processes, 50, 179-211.

Anderson R. E. \& Srinivasan S. S. (2003). E-satisfaction and e-loyalty: a contingency framework. Psychology and Marketing, 20(2), 123-138.

Bae, J., Park, H. H., \& Koo, D. M. (2019). Perceived CSR initiatives and intention to purchase game items: The motivational mechanism of self-esteem and compassion. Internet Research, 29(2), 329-348.

Banerjee, S. \& Yadav, P. (2012). Analysis of visual merchandising: affect on consumer buying behaviour. International Journal of Retailing \& Rural Business Perspectives, 1(2), 209.

Barber, B. (1983). The Logic and Limits of Trust. New Brunswick, NJ: Rutgers University Press.

Baum, D., Spann, M., Füller, J., \& Thürridl, C. (2019). The impact of social media campaigns on the success of new product introductions. Journal of Retailing and Consumer Services, 50, 289-297.

Belleau, B. D., Summers, T. A., Xu, Y., \& Pinel, R. (2007). Theory of Reasoned Action: Purchase Intention of Young Customers. Clothing and Textiles Research Journal, 25, 244-257.

Bhatnagar, A., Misra, H. \& Rao, R. (2000). On risk, convenience, and internet shopping behavior. Communications of the ACM ,43(11), 98-114.

Bilgihan, A., Kandampully, J. A., \& Zhang, T. (2016). Towards a unified customer experience in online shopping environments: antecedents and outcomes. International Journal of Quality and Service Sciences, 8(1), 102-119.

Bitting, E. \& Ghorbani, A. (2004). Protecting e-commerce agents from defamation. Electronic Commerce Research and Applications, 3, 21-38.

Chakraborty, U. (2019). The impact of source credible online reviews on purchase intention: The mediating roles of brand equity dimensions. Journal of Research in Interactive Marketing, 13(2), 142-161.

Chen, W., Tan, B. C. Y. and Chang, K. Ting-Ting,(2009) Advertising Effectiveness on Social Network Sites: An Investigation of Tie Strength, Endorser Expertise and Product Type on Consumer Purchase Intention" (2009). ICIS 2009 Proceedings. Paper 151.http://aisel.aisnet.org/icis2009/151

Choi, Y. K. (2019). Characters' persuasion effects in advergaming: Role of brand trust, product involvement, and trust propensity. Internet Research, 29(2), 367-380.

Constantinides, E. (2004). Influencing the online consumer's behavior: The Web 
experience. Internet Research, 14(2), 111-126.

Das, T. K. \& Teng, BS. (2004). The Risk-Based View of Trust: A Conceptual Framework, Journal of Business and Psychology. 19(1), 85-116.

Dasgupta, P. (1988) Trust as a commodity. In Trust:Making and Breaking Cooperative Relations. Gambetta, D. (ed.), New York: Basil Blackwell, 49-72.

Davis, F. D. (1989). Perceived usefulness, perceived ease of use, and user acceptance of information technology. MIS Quarterly, 13(3), 319-339.

Ardyanto, D. (2015). Pengaruh Kemudahan Dan Kepercayaan Menggunakan Ecommerce Terhadap Keputusan Pembelian Online (Survei Pada Konsumen Www. petersaysdenim. com). Jurnal Administrasi Bisnis, 22(1).

Fang, Y., Qureshi, I., Sun, H., McCole, P., Ramsey, E., \& Lim, K. H. (2014). Trust, Satisfaction, and Online Repurchase Intention: The Moderating Role of

Perceived Effectiveness of E-Commerce Institutional Mechanisms. MIS Quarterly, 38(2), 407-427.

Fishbein, M., Ajzen I., (1975). Belief, Attitude, Intention, and Behavior: An Introduction to Theory and Research, Addison-Wesley.

Flavian, C. and Guinaliu, M. (2006). Consumer trust, perceived security and privacy policy Three basic elements of loyalty to a web site. Industrial Management \& Data Systems, 106(5), 601-620.

Giddens, A. (1990). The Consequences of Modernity. Cambridge, UK: Polity Press.

Glover, S., \& Benbasat, I. (2010). A comprehensive model of perceived risk of ecommerce transactions. International Journal of Electronic Commerce, 15(2), 47-78.

Good, D. (1988) Individuals, interpersonal relations, and trust. In Trust: Making and

Breaking Cooperative Relations, Gambetta, D. (ed.), New York: Basil Blackwell, 32-47.

Grewal, L., \& Stephen, A. T. (2019). In Mobile We Trust: The Effects of Mobile Versus Nonmobile Reviews on Consumer Purchase Intentions. Journal of Marketing Research, 0022243719834514.

Harris, L.C. and Goode, M.M.H. (2004). The four levels of loyalty and the pivotal role of trust: A study of online services dynamics. Journal of Retailing, 80, 139-158.

Herrando, C., Jimenez-Martinez, J., \& Martin-De Hoyos, M. J. (2019). Tell me your age and I tell you what you trust: the moderating effect of generations. Internet Research. doi:10.1108/intr-03-2017-0135

Hollebeek, L. D., \& Macky, K. (2019). Digital content marketing's role in fostering consumer engagement, trust, and value: Framework, fundamental propositions, and implications. Journal of Interactive Marketing, 45, 27-41.

Jarvenpaa, S. L., Tractinsky, N. and Vitale, M. (2000). Consumer trust in an Internet store. Information and Technology Management, 1, 45-71.

Keller, K. L. (1993). Conceptualizing, Measuring and Managing Customer-Based Brand Equity. The Journal of Marketing, 57(1), 15-16.

Kim, D. J., Ferrin, D. L. \& Rao, H. R. (2008). A trust-based consumer decision-making model in electronic commerce: The role of trust, perceived risk, and their antecedents. Decision Support Systems, 44, 544-564.

Klopping, I. M. \& McKinney, E. (2004). Extending the Technology Acceptance Model and the Task-Technology Fit Model to Consumer E-Commerce. Information Technology, Learning, and Performance Journal, 22(1), 35-48.

Kotler, P. \& Keller, K. L. (2006). Marketing Management, 12th edition, Pearson Prentice Hall Inc., Upper Saddle River, New-Jersey, US.

Koufaris, M. Hampton-Sosa, W. (2004). The development of initial trust in an online 
company by new customers. Information \& Management, 41, 377-397.

Ling, K. C., Bin Daud, D., Piew, T. H., Keoy, K. H., \& Hassan, P. (2011). Perceived risk, perceived technology, online trust for the online purchase Intention in Malaysia. International Journal of Business and Management, 6(6), 167.

Lowe, B., Dwivedi, Y. K., \& d'Alessandro, S. (2019). Consumers and technology in a changing world. European Journal of Marketing, 53(6), In press.

Luhmann, N. (2000). Familiarity, confidence, trust: problems and alternatives in Gambetta, D. (Ed.), Trust: Making and Breaking Cooperative Relations, B. Blackwell, New York, NY, 94-107.

McClure, C., \& Seock, Y. K. (2020). The role of involvement: Investigating the effect of brand's social media pages on consumer purchase intention. Journal of Retailing and Consumer Services, 53, 101975.

McKnight, D. H., Chervany, N. L., (2000). What is Trust? A Conceptual Analysis and an Interdisciplinary Model. Americas Conference on Information Systems (AMCIS)

2000 Proceedings, AIS Electronic Library (AISeL). http://aisel.aisnet.org/amcis2000/382

Moorman, C., Deshpande, R., \& Zaltman, G. (1993). Factors affecting trust in market research relationships. The Journal of Marketing, 57(1) 81-101.

Morgan, R. M., \& Hunt, S. D. (1994). The commitment-trust theory of relationship marketing. The Journal of Marketing, 58(3), 20-38.

Nysveen H., Pedersen, P. E. \& Thorbjørnsen, H. (2005). Intentions to Use Mobile Services: Antecedents and Cross-Service Comparisons. Journal of the Academy of Marketing Science. 33(3), 330-346.

Pavlou, P. A. (2003). Consumer acceptance of electronic commerce: Integrating trust and risk with the technology acceptance model. International journal of electronic commerce, 7(3), 101-134.

Pavlou, P. A. and Fygenson, M. (2006), "Understanding and Predicting Electronic Commerce Adoption: An Extension of the Theory of Planned Behavior", MIS Quarterly, Vol. 30, No.1, pp. 115-143.

Prentice, C., Han, X. Y., Hua, L. L., \& Hu, L. (2019). The influence of identity-driven customer engagement on purchase intention. Journal of Retailing and Consumer Services, 47, 339-347.

Qureshi, I. M., Khan, M. A., \& Ahmad, H. M. (2012). Measuring the effect of E-Marketing Stimuli on Consumer Perception: A scale development study , (130), 144-150.

Remaud, H., \& Lockshin, L. (2009). Building brand salience for commodity-based wine regions. International Journal of Wine Business Research, 21(1), 79-92.

Romaniuk, J. \& Sharp, B. (2004). Conceptualizing and measuring brand salience. Marketing theory, 4(4), 327-342.

Stokburger-Sauer, N., Ratneshwar, S., \& Sen, S. (2012). Drivers of consumer-brand identification. International journal of research in marketing, 29(4), 406-418.

Stewart, K. J. (2003). Trust transfer on the World Wide Web. Organization Science, 14(1),

/.>>>>>.5-17.

Sundararajan, A. (2019). Commentary: The Twilight of Brand and Consumerism? Digital Trust, Cultural Meaning, and the Quest for Connection in the Sharing Economy. Journal of Marketing, 83(5), 32-35.

Thomas, M. J., Wirtz, B. W., \& Weyerer, J. C. (2019). Determinants of online review credibility and its impact on consumers' purchase intention. Journal of Electronic Commerce Research, 20(1), 1-20. 
Vieceli, J. and Shaw, R.N., 2010. Brand salience for fast-moving consumer goods: An empirically based model. Journal of marketing management, 26(13-14), 12181238.

Walczuch, R., \& Lundgren, H. (2004). Psychological antecedents of institution-based consumer trust in e-retailing. Information \& Management, 42(1), 159-177.

Wang, F. and Head, M., 2007. How can the web help build customer relationships: an empirical study on e-tailing. Information \& Management, 44(2), 115-129.

Weisberg, J., Te'eni, D., \& Arman, L. (2011). Past purchase and Intention to purchase in e-commerce: the mediation of social presence and trust. Internet Research, 21(1), 82-96.

Zeithaml, V. A. (1988). "Consumer perceptions of price, quality, and value: A means-end model and synthesis of evidence". Journal of Marketing, Vol. 52, pp. 2-22.

Zhang, T., Wang, W. Y. C., Cao, L., \& Wang, Y. (2019). The role of virtual try-on technology in online purchase decision from consumers' aspect. Internet Research.

Zhao, H., Cheng, X., Wang, X., \& Qin, C. (2019). Do brand micro-blogs entities' interactivity enhance customer's brand resonance? Evidence from China. Asian Business \& Management, 1-19.

Zinko, R., Stolk, P., Furner, Z., \& Almond, B. (2019). A picture is worth a thousand words: how images influence information quality and information load in online reviews. Electronic Markets, 1-15.

Zwass, V. (1998). Structure and macro-level impacts of electronic commerce: From technological infrastructure to electronic marketplaces. In K.E. Kendall (ed.), Emerging Information Technologies, Sage, CA, 289-315. 